\title{
About the Development of Higher Vocational Computer Application Technology Curriculum System
}

\author{
Lingyan Wang \\ Taiyuan Communication university of Shanxi, 030051Shanxi, China
}

Keywords: Computer courses; Curriculum development; Higher vocational education

\begin{abstract}
The development of modern society puts forward higher requirements on talent, which requires the students should not only master the textbook theory knowledge, but also practical operation ability. To this end, the course reform of higher vocational college must pay more attention to the cultivation of students' practical ability, provide more practice opportunities for students, in order to meet the social demand for talents. Change the traditional classroom teaching mode, to rich and colorful forms of classroom teaching, improve students' comprehensive quality.
\end{abstract}

\section{Introduction}

Higher vocational education, as the name implies, is a specialized in view of the vocational education mode. The ultimate goal of higher vocational education is to cultivate a group of professional technical talents for the enterprise, therefore, educators in China's current economic development needs, current situation of the development of industry and enterprise demand for talented person must have a clear understanding. As a place for the education, higher vocational education colleges and universities first need to understand each student's development, only in this way they can better guide the students in the right direction. Put on the talent requirements of enterprises and school education together, arrange mutual combination of theory and practice of curriculum for students. With the continuous popularity of the Internet, computer technology and the application scope of areas will be more and more widely. In order to better adapt to the needs of the development of computer technology, vocational colleges must develop more practical use of the computer application course. Curriculum reform is not a theory, it needs to be based on the needs of the student and the enterprise on the talent requirements. Promote the curriculum development and reform, for the students to develop more courses, with field can help student's better grasp of computer professional theory knowledge, improve the ability and the ability of independent thinking.

\section{Computer Curriculum Development should be Based on the Enterprise to Talented Person's}

\section{Technical Requirements}

The 21st century is a century with computer technology as the core, compared with the other professional, computer professional application is wider. Therefore, before the course reform of the computer professional, vocational colleges must first clear the teaching tasks and goals. Goal orientation is correct, can directly influence the curriculum reform achieve satisfactory results. First of all, against computer major in higher vocational colleges need to a series of studies, including the professional obtain employment prospect, enterprise personnel requirements for computer major, computer applications, and so on. Professional curriculum reform in higher vocational colleges is not unilaterally, it enterprises and schools need to cooperate with each other, accurate positioning of talent, only in this way, school to train a large number of high-quality talents for the enterprise. Computer professional student's employment areas including computer maintenance, web design, application development, multimedia and so on. As a result, the students master the theoretical knowledge is not enough, only in higher vocational colleges must develop more practical courses for students; improve the students' practical ability. In addition, higher vocational colleges should 
also encourage students to participate in the relevant professional training, through a variety of ways to improve their comprehensive quality.

Higher vocational education colleges in the computer specialized curriculum reform development, must be clear the following three aspects: the content of the enterprise to the requirement of talents, the responsibility of different jobs, students should have the ability. Only clear direction to the computer professional talents cultivation in higher vocational colleges to cultivate conforms to the enterprise needs comprehensive technical personnel.

Computer Professional Obtain Employment Requirements. Corresponding requirement for professional staff to familiar with the basic software, application to office equipment, familiar with the operation of the CAD drawing software, and have a basic drawing, design products independently, in accordance with the requirements of the enterprise as a new product for promotion. Requirements: the ability of the module to be able to familiar with common drawing software of CAD, have a certain level of product design, familiar to computer software.

The Ability Requirements of the Development System. Development system of job responsibility: familiar with classification of computer programming language, using $\mathrm{C}$ language, $\mathrm{C}$ ++ , JAVA and other programming languages, have the basic ability of design programs and interfaces, be familiar with all kinds of basic software to write. Capacity requirements of the module to the employees: to understand and computer related theory knowledge, to know every link of system development and the need to use the software, basic grasp the simple programming language.

The Duties of a Multimedia Production and Capacity Requirements. Multimedia production functions and responsibilities of employees: to understand the basic steps of multimedia production and independently complete the information collection and sorting of materials, to be able to use all kinds of software for multimedia design, has the team cooperation spirit. The module of employment capacity requirements: familiar with the basic skills of audio and video processing, can turn a single image is presented in the form of animation, have the ability to independent production of multimedia cd-rom.

Website Development, Maintenance, Management Practitioners Responsibility and Capacity Requirements. Website maintenance, development, management functions and responsibilities of personnel: responsible for website operation test, have the ability to purchase the right equipment, know how to test the computer, can be competent for web development and design work, familiar with the process of website maintenance, able to write a complete network engineering design. The module of employment capacity requirements: familiar with the computer's basic composition, able to computer maintenance work independently, have a certain computer repair experience, familiar with web design, using the network system can independently in different forms and contents of the website. Different positions for the employees of specific capacity requirements will also be different.

Above all, to reform of computer courses in vocational college, you must first for each module. Then according to the different targeted teaching module, the above several modules have similarities in the course, also have differences. In the process of teaching in higher vocational colleges, therefore, must seek common ground while putting aside differences, pay attention to cultivate students' ability of comprehensive development, not only for a certain teaching module.

The computer is a practical very strong professional, it not only demands students to master the basic theoretical knowledge, but also have the ability to practice, to solve problems independently. The development of the modern enterprise of talent put forward higher request, this requires that in the process of cultivating talents in higher vocational colleges must pay attention to the combination of theory and practice.

Second, the curriculum reform of computer professional technology should be based on students' employment direction and jobs

In order to improve the students' learning efficiency, higher vocational colleges and universities to adopt new teaching mode, and the task driving law is one of them. There is no denying the fact that the students more recognition for this learning mode. Computer knowledge and technology 
learning is a process of improve students' comprehensive ability, the professional curriculum reform must be based on the student employment requirement for power in the future. According to the different positions of responsibility and ability request to reform the current computer application course, increase the practical teaching, improve students' speaking ability.

The characteristics of computer professional itself has no copy, specific as follows: (1) through a variety of ways to complete tasks associated with the computer technology, and the results there are many possibilities; (2) the computer job requires a more rigorous, it needs the operator feasible plan, seriously implement and testing on the final results, (3) the computer plays an indispensable role in the electronic information industry, the development of it has profound significance; (4) it can be the unique characteristic of the computer in the work.

With the continuous development of society, electronic information technology is also in constant progress, in other words, the enterprise to the requirement of talent is also changing, in order to make students better adapt to the enterprise requirement for talents, higher vocational colleges must deepen the reform of the computer professional courses. The ultimate goal of higher vocational education is to cultivate professional technical talents for the society, therefore, the school cannot be stuck in the past, but should according to the development of the students need to make a new attempt. This new type of teaching mode, make full use of task driving method, improve the enthusiasm of the students. Nowadays, higher vocational colleges in a course is basic it is strictly abided by during the courses by the principle of a teacher in charge, this is not conducive to the students will be mutual combination of theoretical knowledge and practical operation. If the teacher just blindly the textbook knowledge to the students, so students' learning effects will be difficult to guarantee. Only to improve students' ability to apply theoretical knowledge to practical operation is to cultivate students to become comprehensive talents. Test whether students really master textbook knowledge, you must let the student independently, rather than a step by step according to the steps of the books.

In the study of computer professional students in higher vocational colleges, many will choose his apprenticeship program development of related work. In front of the computer science curriculum reform in higher vocational colleges, the teacher should understand students' employment intention and enterprises on the talent requirements, and other factors. On this basis, according to different students' development needs, design a different technology course, in-depth interpretation of the theoretical knowledge, make every student can master the basic knowledge of computer science. Teaching content must adapt with the requirements of the development of The Times and technology, at the end of the course teaching, let the student independently to complete tasks assigned by the teacher training, help students to consolidate the theoretical knowledge. Task driving method is used to improve the students' initiative, to rich and colorful form of teaching content, training students' comprehensive development. The cultivation of ability and quality must be synchronized, be short of one cannot, let students understand the computer related professional ethics, professional ethics are also very important. In the course of computer specialty teaching, the introduction of the relevant knowledge of the industry, popularization of the computer professional legal knowledge to all the students. Change teaching idea, lets the student understand computer professional employment prospects, through improving student's comprehensive ability, make it more in line with the enterprise demand for talent.

\section{Conclusion}

Higher vocational computer application technology development and construction of curriculum is a great work, not can be done overnight. This course system not only involves the quality of the classroom, the teaching content, but also involves the cultivation of practice ability after class. In the teaching system in the process of development, should pay attention to the cultivation of practice ability, make the teaching content and the way to present in practice, the teaching way and the reality, set up perfect teaching system.

In practice teaching, can be in the form of school and enterprise cooperation to lead students to 
work-integrated learning pattern, lets the student can from practice to feel job functions, to prepare for the future of the work ahead of time. Actual operation training, is crucial for students, theory only mastering enough again did not practice is an armchair strategist. So, teaching process need to be well prepared, at the same time of training students' practical ability and creativity, improve the quality of teaching.

\section{References}

[1] In for zhou. About the development of higher vocational computer application technology curriculum system. The vocational education BBS. 2011

[2] $\mathrm{Wu}$. About the development of higher vocational computer application technology curriculum system. "The science and technology to become rich wizard". 2013

[3] Nov. Higher vocational computer application technology professional website development direction of curriculum system construction. "Journal of institute of yichun. 2013

[4] Lv Yan. Higher vocational computer application technology professional curriculum development countermeasures research. "Journal of liaoning vocational college. 2010

[5] Ya-lin wang, qing-yu meng. Higher vocational counterparts, enters a higher school computer application technology professional curriculum system development research. "The development and application of the computer." 2015 